\title{
Fasudil may induce the differentiation of bone marrow mesenchymal stem cells into neuron-like cells via the Wnt/B-catenin pathway
}

\author{
YAHUI HU ${ }^{1}, \mathrm{XIN} \mathrm{LI}^{1}$, GUOWEI HUANG ${ }^{2}$, JIZUO WANG ${ }^{1}$ and WEI LU ${ }^{1}$ \\ ${ }^{1}$ Department of Neurology, The Second Hospital of Tianjin Medical University, Tianjin 300211; \\ ${ }^{2}$ Department of Nutrition and Food Hygiene, School of Public Health, Tianjin Medical University, Tianjin 300070, P.R. China
}

Received May 30, 2016; Accepted February 18, 2019

DOI: $10.3892 / \mathrm{mmr} .2019 .9978$

\begin{abstract}
Bone mesenchymal stem cells (MSCs) are an excellent donor graft source due to their potential for self-renewal and multidirectional differentiation. However, it is difficult to obtain high quality MSCs and to induce them to differentiate into neuron-like cells. Fasudil, a Rho kinase inhibitor, exhibits therapeutic potential in spinal cord injuries and stroke. The present study investigated the effect of fasudil on the differentiation of MSCs into neuron-like cells. MSCs were obtained from rat femur marrow, expanded in culture medium, and used at the third passage for subsequent experiments. MSCs were pre-induced with $10 \mathrm{ng} / \mathrm{ml}$ basic fibroblast growth factor (bFGF) for $24 \mathrm{~h}$, which was followed by induction with fasudil. A control untreated group and a group treated with fasudil + XAV939, a Wnt/ $\beta$-catenin pathway inhibitor, were also used in the present study. Reverse transcription-quantitative polymerase chain reaction (RT-qPCR), western blot analysis and immunofluorescence staining were performed in order to detect neuron-specific markers, including neuron-specific enolase (NSE), nestin and neurofilament-M (NF-M). Following induction with fasudil, neuron-like cell morphology was observed. In the fasudil + XAV939 and control groups, no obvious changes in cell shape were observed. The results of RT-qPCR, western blot analysis and immunofluorescence staining indicated that expression of the neuron-specific markers NSE, nestin and NF-M was detected in the fasudil group. The differentiation
\end{abstract}

Correspondence to: Dr Xin Li, Department of Neurology, The Second Hospital of Tianjin Medical University, 23 Pingjiang Road, Hexi, Tianjin 300211, P.R. China

E-mail: lixin66661@163.com

Dr Guowei Huang, Department of Nutrition and Food Hygiene, School of Public Health, Tianjin Medical University, 22 Qixiangtai Road, Heping, Tianjin 300070, P.R. China

E-mail: huangguowei@tmu.edu.cn

Key words: bone marrow mesenchymal stem cells, fasudil, differentiation, neuron-like cells, Wnt/ $\beta$-catenin pathway of MSCs into neuron-like cells induced by fasudil was eliminated when the Wnt/ $\beta$-catenin pathway was inhibited. The present study demonstrated that fasudil may induce MSCs to differentiate into neuron-like cells, however further studies are required to determine the specific mechanisms involved in the effect of fasudil on the $\mathrm{Wnt} / \beta$-catenin pathway. In addition, further research is required to examine the functional characteristics of the induced neuron-like cells, in order to establish their suitability for clinical treatments in the future.

\section{Introduction}

The bone marrow contains two types of stem cells: Hematopoietic stem cells and bone mesenchymal stem cells (MSCs). MSCs have the capacity to differentiate into various cell types, including muscle cells, cardiac muscle cells, hepatocytes, astrocytes, neurons, hematopoietic cells and myogenic elements (1-4). Furthermore, administration of MSCs has therapeutic benefits in animal models of cerebral ischemia and trauma (5-8). Additional studies have indicated that MSCs promote peripheral nerve regeneration, and maybe used as a cell substitution therapy for central nervous system injury and retrograde diseases (9-11). Given their potential, MSCs are presently a topic of intense interest in life sciences research.

A variety of chemicals and growth factors have been previously demonstrated to induce transdifferentiation of MSCs into neural-like cells in vitro (12-14). However, it has also been reported that the morphological changes and immunoreactivity for neural markers in cultured MSCs induced by these treatments may be associated with cellular toxicity, cell shrinkage and cytoskeletal changes, therefore indicating that the efficiency of differentiation is unstable (12-15).

Fasudil is a specific inhibitor of Rho kinase (ROCK) and previous studies have indicated that ROCK is directly implicated in neuronal damage (16-19). Inhibition of ROCK was reported to reduce apoptosis in embryonic stem cell-derived neural precursor cells following transplantation (20). Another report indicated that fasudil protects against ischemia-induced delayed neuronal death when treatment is initiated $24 \mathrm{~h}$ following ischemia (21). In addition, fasudil is reported to induce the proliferation and differentiation of adult brain neural stem cells in the subventricular zone in mice following hypoxia/reoxygenation injury (22). Several 
studies, including preliminary results from the present study, have demonstrated that fasudil induces bone marrow MSCs to differentiate into neuron-like cells (23-25). The mechanisms involved in this process remain unclear, however, previous reports have indicated that the $\mathrm{Wnt} / \beta$-catenin signaling pathway is involved in regulating MSC differentiation into neuron-like cells $(26,27)$, and that cross-talk exists between the Wnt/ $\beta$-catenin signaling pathway and the ROCK pathway (28-30). Therefore, the present study tested the hypothesis that the $\mathrm{Wnt} / \beta$-catenin signaling pathway may mediate the fasudil-induced differentiation of MSCs into neuron-like cells.

\section{Materials and methods}

Animals. A total of 4 male Sprague-Dawley rats (postnatal, 4-6 weeks old; weight, 150 g) were purchased from the Animal Center of Genetics and Developmental Biology Laboratory of the Chinese Academy of Science (Beijing, China). Animals were housed under a 12-h light/dark cycle, with free access to food (standard laboratory chow diet from the Animal Center of Genetics and Developmental Biology Laboratory, Beijing, China) and water ad libitum. The housing temperature was controlled between 18 and $26^{\circ} \mathrm{C}$, and humidity was between 40 and $60 \%$. Ethical approval for animal experiments was obtained from the Committee on the Use of Live Animals in Teaching and Research of The Second Hospital of Tianjin Medical University (Tianjin, China).

Reagents. $\alpha$-minimum essential medium ( $\alpha$-MEM), trypsin and low glucose-Dulbecco's modified Eagle's medium (L-DMEM) were obtained from Gibco (Thermo Fisher Scientific, Inc., Waltham, MA, USA). Fetal bovine serum (FBS) and EDTA were obtained from Sigma-Aldrich (Merck KGaA, Darmstadt, Germany). Fasudil was purchased from Tianjin Chase Sun Pharmaceutical Co., Ltd. (Tianjin, China). Mouse primary antibodies against CD44 (sc-65876), CD34 (sc-65261), CD45 (sc-1178), CD29 (sc-9970), CD31 (sc-18916) and CD90 (sc-69396) were purchased from Santa Cruz Biotechnology, Inc. (Dallas, TX, USA), and fluorescein isothiocyanate (FITC)-conjugated goat anti-mouse IgG secondary antibody (ZF-0312) was purchased from OriGene Technologies, Inc. (Beijing, China). Basic fibroblast growth factor (bFGF) was obtained from PeproTech, Inc. (Rocky Hill, NJ, USA). XAV-939 (Wnt/ $\beta$-catenin pathway inhibitor; S1180) was purchased from Selleck Chemicals Co., Ltd. (Houston, TX, United States).

Separation and culture of MSCs. Rat femurs were extracted under aseptic conditions. Marrow cells were washed out with $2 \mathrm{ml}$ L-DMEM containing 10\% FBS. Following centrifugation at $4^{\circ} \mathrm{C}$ with $150 \mathrm{xg}$ for $5 \mathrm{~min}$, the supernatant and fat layer was discarded. Standard culture medium (containing 10\% FBS, $\alpha$-MEM, $100 \mathrm{U} / \mathrm{ml}$ penicillin and $100 \mu \mathrm{g} / \mathrm{ml}$ streptomycin) was added to the precipitate and thoroughly mixed. The cells were incubated in a humidified atmosphere containing 95\% air and $5 \% \mathrm{CO}_{2}$. After $24 \mathrm{~h}$, fresh medium was added and non-adherent cells were discarded. The medium was then changed every other day. When MSCs reached 80-90\% confluence, they were digested by $0.25 \%$ trypsin containing $0.02 \%$ EDTA for 3-5 min, and digestion was terminated by adding standard culture medium. Following centrifugation $\left(4^{\circ} \mathrm{C}, 150 \mathrm{xg}, 5 \mathrm{~min}\right)$, the supernatant was removed and standard culture medium (diluted 1:2) was added for further expansion. Cell growth was observed every day under an inverted phase contrast microscope. Specimens from the third or fourth passage of MSCs were used for the subsequent experiments.

\section{Identification of MSCS}

MSC growth curve determination. Third passage MSCs with good growth were digested with $0.25 \%$ trypsin to make single cell suspension, then cells $\left(1 \times 10^{4} / \mathrm{ml}\right)$ were inoculated on a 96-well culture plate. Each group was made in triplicate, and placed in an incubator at $37^{\circ} \mathrm{C}$ and $5 \% \mathrm{CO}_{2}$ for $1-7$ days, during which time the medium was changed every other day. Starting at the second day, $20 \mu \mathrm{l}$ MTT $(5 \mathrm{mg} / \mathrm{ml})$ was added every morning, and incubated for $4 \mathrm{~h}$. Following medium removal, $150 \mu 1$ dimethyl sulfoxide was added at room temperature for $10 \mathrm{~min}$. The absorbance value of each well was detected at $490 \mathrm{~nm}$ wavelength with a spectrophotometer.

Flow cytometry. Third passage MSCs $\left(1 \times 10^{4} / \mathrm{ml}\right)$ were carefully suspended in the residual volume of staining buffer and then $200 \mu \mathrm{l}$ of freshly prepared cold fixation buffer (Haoran bioscience, Inc., Shanghai, China ) was added. To fix the cells, they were then incubated for $30 \mathrm{~min}$ at $4^{\circ} \mathrm{C}$ in the dark. Then, the sample was centrifuged at 1,000 $\mathrm{x}$ g for $5 \mathrm{~min}$ and the fixative removed. To permeabilize the cells, careful suspension of the cell pellet in another $200 \mu \mathrm{l}$ of freshly prepared pre-warmed $\left(37^{\circ} \mathrm{C}\right)$ permeabilization buffer (Haoran Bioscience, Inc.) was performed and the cells were then incubated for $30 \mathrm{~min}$ at $37^{\circ} \mathrm{C}$ in the dark. Next, the cells were centrifuged at $1,000 \times \mathrm{g}$ for $5 \mathrm{~min}$ and the buffer removed. To wash the cells, $200 \mu \mathrm{l}$ of PBS was added to each tube, centrifuged at $1,000 \mathrm{x}$ g for $5 \mathrm{~min}$ and then the buffer removed. Blocking was performed with $10 \%$ goat serum (Thermo Fisher Scientific, Inc.) at $37^{\circ} \mathrm{C}$ for $2 \mathrm{~h}$. Then, the cells were labeled with CD34 (1:2,000; cat. no. ab81289), CD44 (1:2,000; cat. no. ab157107), CD29 (1:2,000; cat. no. ab30394) and CD45 (1:2,000; cat. no. ab10558) (all from Abcam, Cambridge, UK) at room temperature in the dark for $30 \mathrm{~min}$. The cells were then washed with PBS to remove any unbound antibodies. Cells were then incubated with FITC-labeled goat anti-mouse secondary antibody (1:5,000; cat. no. ab6785; Abcam) at $37^{\circ} \mathrm{C}$ for $30 \mathrm{~min}$. The stained cells were analyzed using a Becton-Dickinson FACScan flow cytometer using WinMD I software (version 2.9; BD Biosciences, Franklin Lakes, NJ, USA).

Cell treatment and morphological observation. Third passage MSCs $\left(1 \times 10^{4} / \mathrm{ml}\right)$ were seeded into $24-w e l l$ plates with a prepared coverslip in an incubator at $37^{\circ} \mathrm{C}$ and $5 \% \mathrm{CO}_{2}$. The culture medium consisted of $10 \%$ FBS in $\alpha$-MEM. When cells reached $\sim 80-90 \%$ confluence, the medium was removed and pre-induction solution (culture medium containing $10 \mathrm{ng} / \mathrm{ml} \mathrm{bFGF}$ ) was added to each well for $24 \mathrm{~h}$, after which the pre-induction solution was removed. Subsequently, DMEM with $10 \% \mathrm{FBS}$ and $200 \mu \mathrm{mol} / 1$ fasudil was added to the fasudil group, DMEM with 10\% FBS, $200 \mu \mathrm{mol} / 1$ fasudil and $8 \mu \mathrm{mol} / 1$ XAV939 was added to the fasudil + XAV939 group, and DMEM with $10 \%$ FBS alone was added to the control group. Morphological cell changes were observed with an inverted light microscope following induction for 6, 24 and $48 \mathrm{~h}$. 
Table I. Sequences of primers used in reverse transcription-quantitative polymerase chain reaction.

Primer sequences (5'-3')

\begin{tabular}{lll}
\cline { 2 - 3 } Gene name & \multicolumn{1}{c}{ Forward } & \multicolumn{1}{c}{ Reverse } \\
\hline Neuron-specific enolase & GGAGAACAGTGAAGCCTTGG & GGTCAAATGGGTCCTCAATG \\
Nestin & AGCTGGCGCACCTCAAGATG & AGGGAAGTTGGGCTCAGGAC \\
Neurofilament-M & GAGGCGGCCAGTTATCAGGA & GTTCTCCTCGCCCTCTAGCA \\
$\beta$-catenin & GAGTGCTGAAGGTGCTGTCT & ATCCCTTCCTGCTTAGTCGC \\
$\beta$-actin & AGGCCAACCGTGAAAAGATG & ACCAGAGGCATACAGGGACA
\end{tabular}

Reverse transcription-quantitative polymerase chain reaction $(R T-q P C R)$. Following induction of the three groups for $24 \mathrm{~h}$, total RNA was extracted using TriPure Isolation Reagent (Roche Diagnostics, Indianapolis, IN, USA) and RNA concentrations were measured using a NanoDrop spectrophotometer (Thermo Fisher Scientific, Inc.), RNA ( $2 \mu \mathrm{g})$ was reverse-transcribed using the All-in-One First-Strand cDNA Synthesis kit (QP009; GeneCopoeia, Inc., Rockville, MD, USA). The transcripts of interest and housekeeping gene $\beta$-actin were amplified from cDNA using the SYBR-Green-based All-in-One qPCR Mix (GeneCopoeia, Inc.) and specific primers. Primer sequences are listed in Table I. Amplification and detection were performed on a real-time PCR detection system as follows: Denaturation at $95^{\circ} \mathrm{C}$ for $10 \mathrm{~min}$ and 40 cycles of denaturation at $95^{\circ} \mathrm{C}$ for $10 \mathrm{sec}$, annealing at $60^{\circ} \mathrm{C}$ for $20 \mathrm{sec}$ and extension at $72^{\circ} \mathrm{C}$ for $15 \mathrm{sec}$. Each sample was in two parallel cavities and tests were performed in triplicate. The results were analyzed using the $2^{-\Delta \Delta \mathrm{Cq}}$ method (31).

Western blot analysis. Following induction of the three groups for $24 \mathrm{~h}$, total protein extracts were collected for western blot analysis. Cells were lyzed in ice-cold radioimmunoprecipitation assay buffer (containing $1 \mu \mathrm{M}$ pepstatin A, $1 \mathrm{mM}$ iodoacetic acid and $0.4 \mathrm{mM}$ PMSF) in the presence of a protease inhibitor cocktail (Roche Diagnostics, Basel, Switzerland). For nuclear $\beta$-catenin, nuclear protein extract was isolated from the lysates using a Nuclear Extract kit (Active Motif, Carlsbad, CA, USA). Protein concentration was quantified by a bicinchoninic acid assay. Protein samples $(30 \mu \mathrm{g})$ were separated on a $12 \%$ sodium dodecyl sulfate gel and transferred to an Immobilon polyvinylidene fluoride membrane (EMD Millipore, Billerica, MA, USA). Membranes were blocked for $1 \mathrm{~h}$ at room temperature in TBST (Tris-buffered saline, 0.1\% Tween-20; Boster Biological Technology Co. Ltd., Hubei, China) and 3\% nonfat dry milk (Nestle Company, Geneva, Switzerland). Membranes were incubated overnight with primary antibodies against neurofilament-M (NF-M; 34-1000; 1:2,000), neuron-specific enolase (NSE; MA5-17072; 1:1,000) (both from Invitrogen; Thermo Fisher Scientific, Inc.), nestin (sc-23927; 1:1,000), $\beta$-catenin (sc-65480; 1:1,000) (both from Santa Cruz Biotechnology, Inc.) and $\beta$-actin (MA5-15739; 1:1,000; Invitrogen; Thermo Fisher Scientific, Inc.) at $4^{\circ} \mathrm{C}$, followed by incubation with a horseradish peroxidase-conjugated secondary antibody (sc-2371; 1:3,000; Santa Cruz Biotechnology, Inc.) for $1 \mathrm{~h}$ at room temperature. Western Blotting Luminol Reagent (sc-2048; Santa Cruz Biotechnology, Inc.) was uniformly added on the transferring membrane, and the results were recorded using a chemiluminescence imaging system (Santa Cruz Biotechnology, Inc.).

Immunofluorescent staining of NSE, NF-M and nestin. Following induction for 6, 24 and $48 \mathrm{~h}$, cells at confluency of $\sim 80-90 \%$ were washed three times with $0.01 \mathrm{M} \mathrm{PBS}(\mathrm{pH} 7.0)$ at $37^{\circ} \mathrm{C}$ and fixed by $4 \%$ paraformaldehyde at room temperature for $30 \mathrm{~min}$. Cells were then washed three times with $0.01 \mathrm{M}$ PBS (3 min each time) and $3 \% \mathrm{H}_{2} \mathrm{O}_{2}$ was added for $10 \mathrm{~min}$ at room temperature to block endogenous peroxidase. The cells were washed again with $0.01 \mathrm{M}$ PBS three times for $3 \mathrm{~min}$ and incubated with $0.1 \%$ Triton X-100 (in PBS) for $20 \mathrm{~min}$ at room temperature. After repeating the wash step, 5\% horse serum (ZLI-902; OriGene Technologies, Inc.) was added for $20 \mathrm{~min}$ at room temperature. The diluted NSE (NSE; MA5-17072; 1:1,000), NF-M (34-1000; 1:1,000) (both from Invitrogen; Thermo Fisher Scientific, Inc.) and nestin (sc-23,927; 1:1,000; Santa Cruz Biotechnology, Inc.) monoclonal antibodies were added and incubated at $4^{\circ} \mathrm{C}$ overnight, with PBS alone added as a control. The culture plate was removed from $4^{\circ} \mathrm{C}$, warmed to room temperature for $20 \mathrm{~min}$, and washed three times with PBS for 3 min. FITC (ZLI-902; 1:100; OriGene Technologies, Inc.)/tetramethylrhodamine-labeled secondary antibodies (ZF-0313; 1:100; OriGene Technologies, Inc.) were added for $2 \mathrm{~h}$ at room temperature, followed by three washes with PBS. NSE, nestin and NF-M-positive cells were counted in three randomly selected non-overlapping visual fields at x100 magnification under an inverted fluorescent light microscope. The proportion of neuron-like cells in total cells was calculated.

Statistical analysis. Data are presented as the mean \pm standard deviation. One-way analysis of variance followed by Dunnett's post hoc test was performed to determine significant differences among the experimental groups. $\mathrm{P}<0.05$ was considered to indicate a statistically significant difference. GraphPad Prism version 5.01 (GraphPad Software, Inc., La Jolla, CA, USA) was used for statistical analysis.

\section{Results}

\section{Identification of Rat MSCs}

Morphological changes under light microscopy. Primary isolated MSCs grew slowly at first, until cells attached to the bottom of the cell culture flask at $48 \mathrm{~h}$, after which they proliferated rapidly. As presented in Fig. 1, on day 7, 80-90\% 

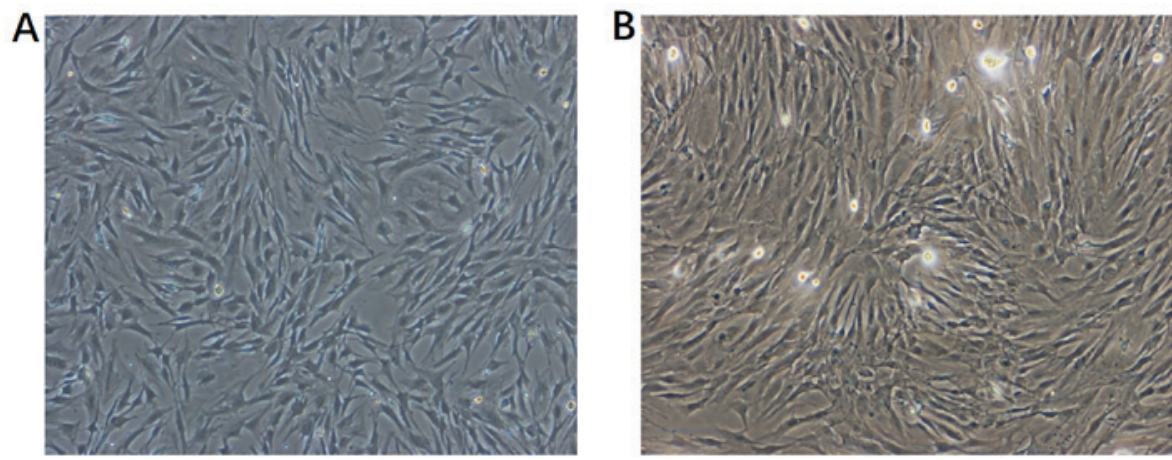

Figure 1. Morphological features of bone mesenchymal stem cells (MSCs) under light microscopy on day 7 of culture. (A) First and (B) third passage of MSCs.
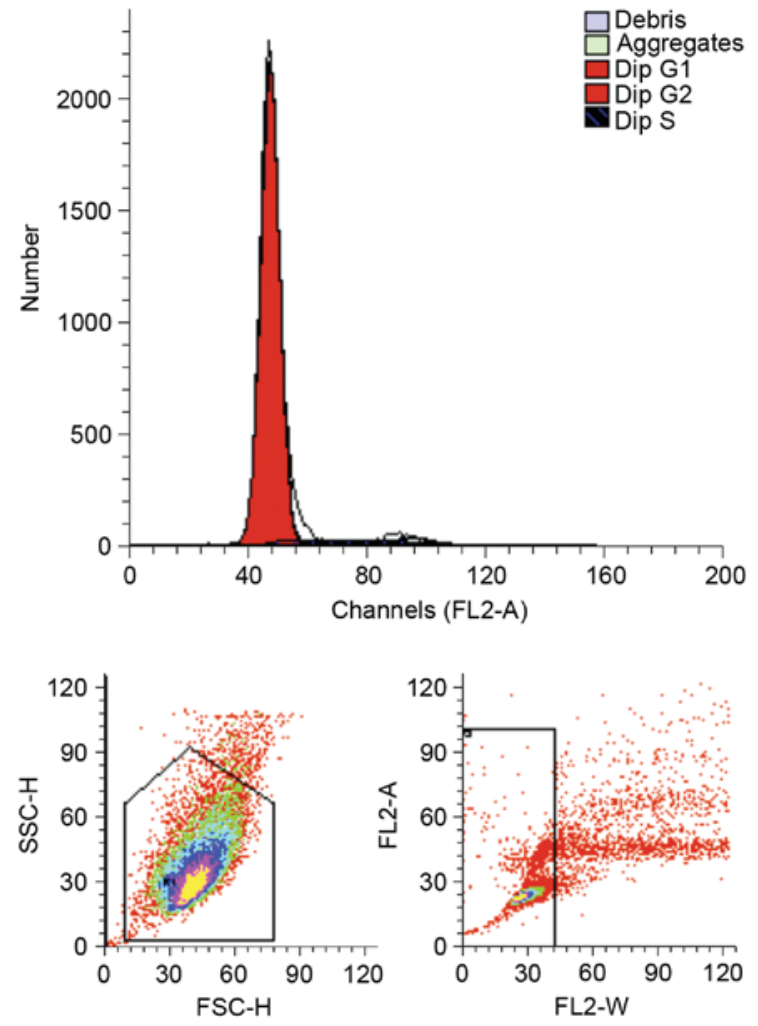

Figure 2. Flow cytometric analysis of the cell cycle. The proportions of undifferentiated bone mesenchymal stem cells at passage 3 in $\mathrm{G0} / \mathrm{G} 1, \mathrm{G} 2 / \mathrm{M}$ and $\mathrm{S}$ phases were $93.99,0.54$ and $5.46 \%$, respectively.

of primary isolated MSCs were attached to the bottom of cell culture flask without overlapping. Then primary culture MSCs were subcultured. Just after passage, MSCs attached completely to the bottom of cell culture flask, spread and changed into a long fusiform morphology. After another $24 \mathrm{~h}$, the cells proliferated rapidly.

Growth curve of MSCs (data not shown). After the first two days, there was no significant change in absorbance, indicating that it was the latent period of cell growth phase. After day 3, absorbance increased significantly, which indicated that there was a logarithmic growth phase and, after the day 6 , absorbance stopped increasing, suggesting that contact inhibition of the cell growth phase had begun. The observed growth pattern was consistent with the growth characteristics of stem cells.
Cell cycle of MSCs. Flow cytometry demonstrated that $93.99 \%$ of third passage MSCs were at the G0/G1 phase, $0.54 \%$ cells were at the $\mathrm{G} 2 / \mathrm{M} 0$ phase and $5.46 \%$ cells were at the S phase, as presented in Fig. 2. These results suggest that the majority of cells were in the resting stage and only a few cells were in the active proliferative phase in vitro, which indicated that the potential of differentiation was consistent with stem cell characteristics.

Surface markers of MSCs. CD29, CD44 are important surface markers of MSCs. MSCs and hematopoietic stem cells both exist in the bone marrow, but MSCs do not express hematopoietic cell surface antigens, including hematopoietic stem cell marker antigen CD34, leukocyte marker antigen CD45. The results of surface marker analysis by flow cytometry indicated that the cells were negative for the expression of CD45, CD34, indicating that the cultured cells were non-hematopoietic cells. In addition, cells were positive for CD29 and CD44, indicating that the cultured cells were MSCs (Fig. 3).

Morphological changes following induction with fasudil. The cell morphology of MSCs pre-induced by $10 \mathrm{ng} / \mathrm{ml}$ bFGF for $24 \mathrm{~h}$ did not change compared with cells without pre-induction (data not shown). As demonstrated in Fig. 4, compared with the control group, cells in the fasudil group began to shrink, changed from spindle-shaped and flat to round and smaller, formed slender processes and presented with neuron-like cellular shapes at $6 \mathrm{~h}$ of incubation. After $24 \mathrm{~h}$, an increased number of neuron-like cells were observed, and certain cells pulled into network-like structures (Fig. 4). After $48 \mathrm{~h}$, cell synapses of MSCs fractured and dissolved, the network-like connections disappeared and the number of cells was reduced (Fig. 4). No marked changes in cell shape were observed in the fasudil + XAV939 group after $6 \mathrm{~h}$, with only a limited amount of cell body shrinkage and no cell processes observed. After 24 and $48 \mathrm{~h}$, some cell processes were observed, but no obvious network-like connection. Compared with the control cells, these cells were larger, more outspread and more fibroblast-like.

$R T-q P C R$ results following induction for $24 \mathrm{~h}$. In order to confirm the neural differentiation of MSCs by fasudil, the mRNA expression levels of the neuron-specific genes NSE, nestin and NF-M were analyzed. It was observed that fasudil-induced cells expressed significantly higher levels of 
A

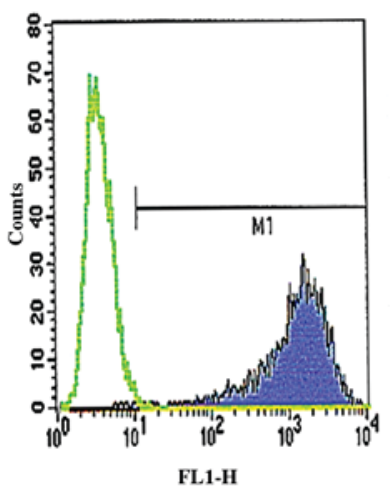

B

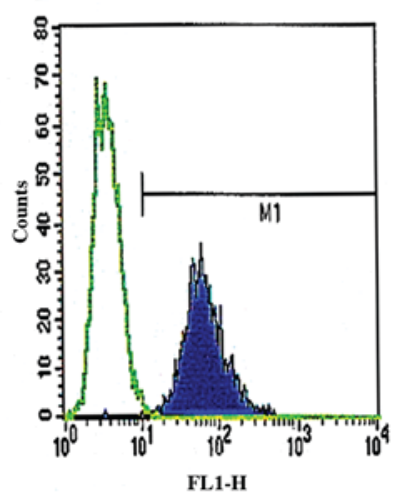

C

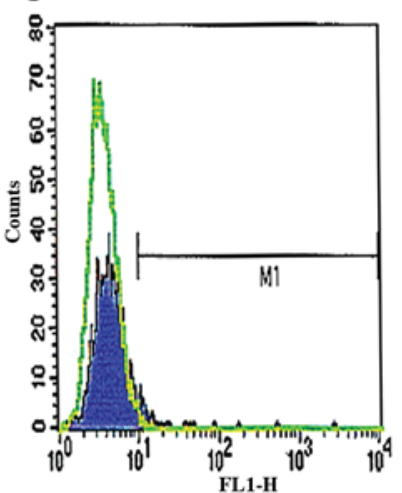

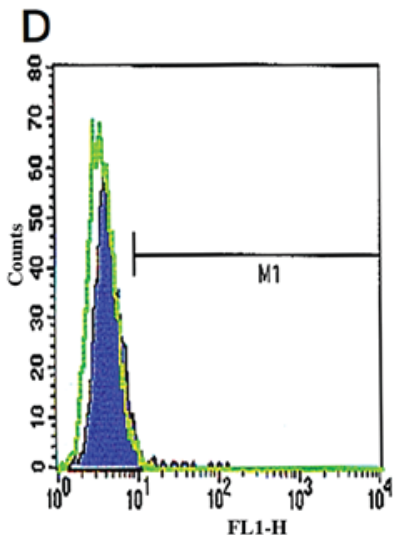

Figure 3. Identification of mesenchymal stem cell surface markers. (A) CD34, (B) CD 45, (C) CD29 and (D) CD44 expression. M1, Marker 1.

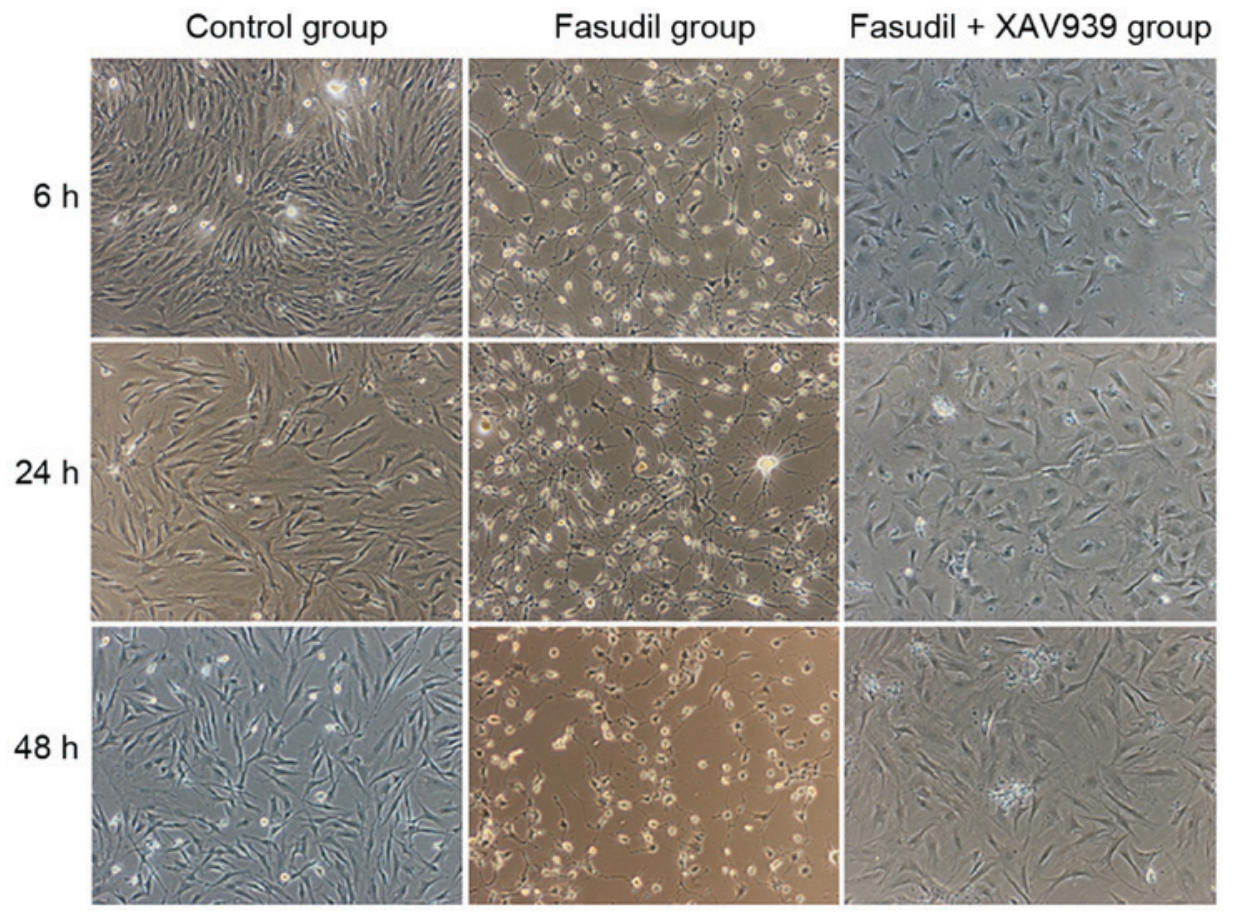

Figure 4. Cell morphology of control, fasudil and fasudil+XAV939 groups after induction for 6, 24 and 48 h (magnification, x40).

mRNA for NSE, nestin and NF-M, compared with the control group $(\mathrm{P}<0.05$; Fig. 5A-C), indicating that genes for neural function were activated in MSCs following induction with fasudil. Compared with the fasudil group, the mRNA expression levels of NSE, nestin and NF-M in the fasudil + XAV939 group was significantly lower $(\mathrm{P}<0.05$; Fig. 5A-C). These results indicate that inhibition of the $\mathrm{Wnt} / \beta$-catenin pathway by the specific inhibitorXAV939 partially reversed the effects of fasudil on MSCs.

The mRNA expression levels of $\beta$-catenin were also investigated. Expression of $\beta$-catenin wasincreased significantly in the fasudil group compared with the control group $(\mathrm{P}<0.05$; Fig. 5D), indicating that fasudil may increaseWnt/ $\beta$-catenin pathway activity in bone marrow MSCs. The expression of $\beta$-catenin mRNA in the fasudil + XAV939 group decreased significantly $(\mathrm{P}<0.05)$ compared with the fasudil group, indicating that the activity of the $\mathrm{Wnt} / \beta$-catenin pathway activity was decreased by the XAV939 specific inhibitor.
Together, these results indicate that fasudil may induce bone marrow MSCs to differentiate into neuron-like cells by enhancing expression of NSE, nestin and NF-M. Furthermore, the results indicate that the $\mathrm{Wnt} / \beta$-catenin pathway may be involved in this process.

Western blot analysis results following induction for $24 \mathrm{~h}$. In order to more accurately detect neuronal cell-associated gene expression changes at the protein level, protein extracts were examined by western blot analysis. As demonstrated in Fig. 6 , the protein expression levels of $\beta$-catenin in the nucleus was increased in the fasudil group compared with the control group, indicating that fasudil may increase the activity of the Wnt/ $\beta$-catenin pathway in bone marrow MSCs. The expression of $\beta$-catenin protein in the fasudil + XAV939 group decreased significantly compared with the fasudil group, indicating the inhibitory effect of XAV939 on the Wnt/ $\beta$-catenin pathway. The expression of nestin, NSE and NF-M significantly 
A

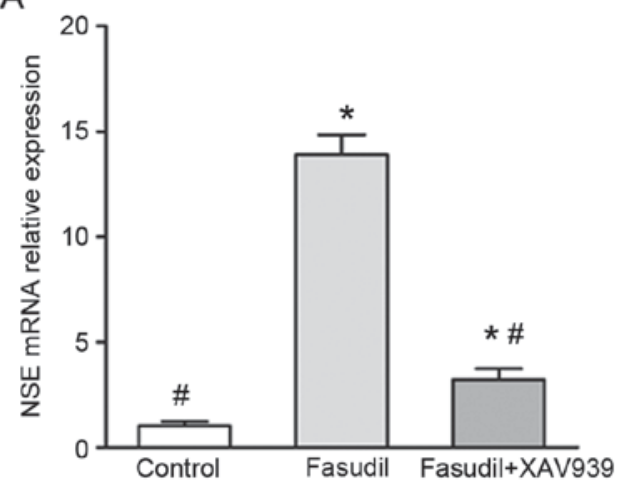

C

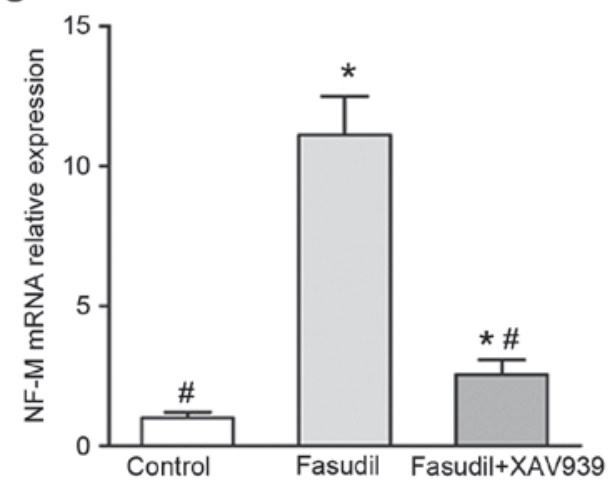

B

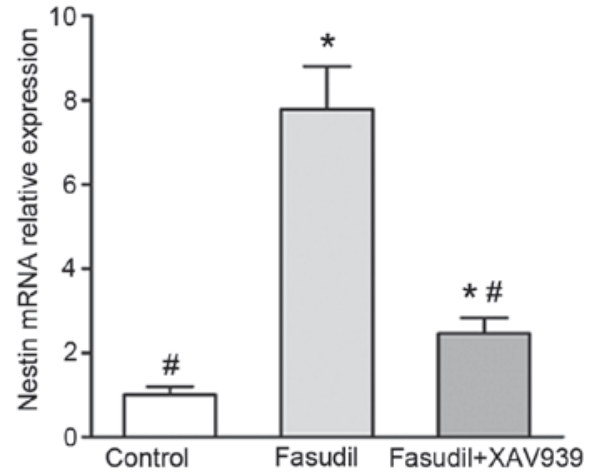

D

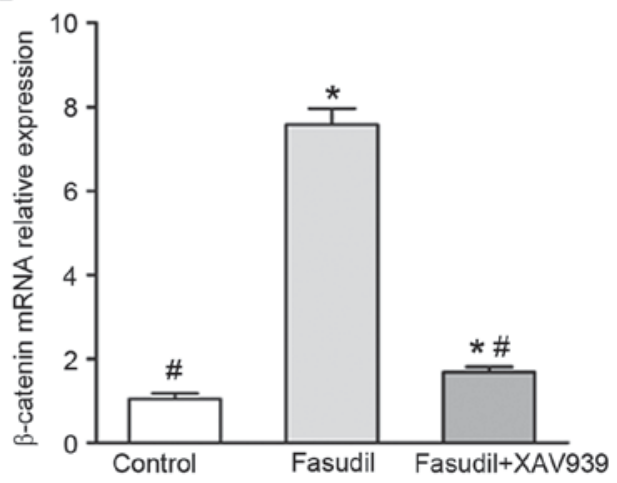

Figure 5. Reverse transcription-quantitative polymerase chain reaction results in control, fasudil and fasudil + XAV939 groups after induction for 24 h. mRNA expression levels of (A) NSE, (B) nestin, (C) NF-M and (D) $\beta$-catenin. NSE, neuron-specific enolase; NF-M, neurofilament-M. *P<0.05 vs. control; and ${ }^{\#} \mathrm{P}<0.05$ vs. fasudil-only group.

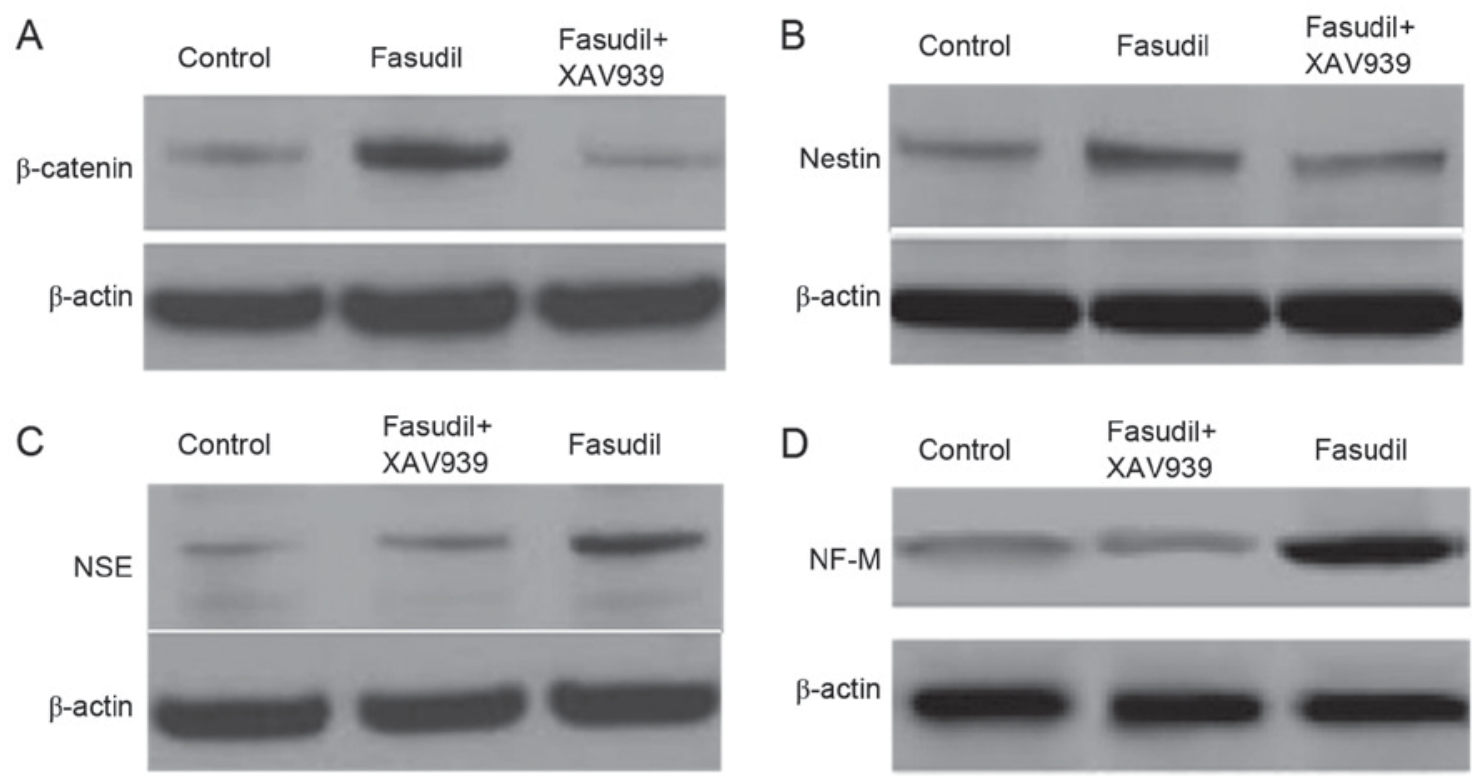

Figure 6. Western blot results in control, fasudil and fasudil + XAV939 groups after induction for 24 h. (A) Nuclear protein expression of $\beta$-catenin, and protein expression of (B) nestin, (C) NSE and (D) NF-M. NSE, neuron-specific enolase; NF-M, neurofilament-M.

increased in the fasudil group compared with the control group, indicating that induction with fasudil caused cells to express the neuronal-specific proteins. Expression of nestin, NSE and NF-M in the fasudil + XAV939 group was similar to the control group, indicating that the differentiation effect of fasudil was eliminated when theWnt/ $\beta$-catenin pathway was inhibited.
Immunofluorescence staining results for NSE, NF-M and nestin. In the control group and fasudil + XAV939 group, no obvious positive immunofluorescent staining cells were observed (data not shown). After cells were induced by fasudil for $6 \mathrm{~h}$, the average positive rate of immunofluorescent staining was $81.93 \%$ for NSE, $33.28 \%$ for NF-M and $39.45 \%$ for 
Table II. Immunofluorescence staining results for NSE, NF-M and nestin in fasudil-induced cells.

\begin{tabular}{clll}
\hline Time, h & NSE $(\%)$ & NF-M $(\%)$ & Nestin $(\%)$ \\
\hline 6 & $81.93 \pm 3.65$ & $33.28 \pm 1.92$ & $39.45 \pm 1.95$ \\
24 & $76.52 \pm 2.99$ & $45.31 \pm 2.96^{\mathrm{a}}$ & $68.81 \pm 3.73^{\mathrm{a}}$ \\
48 & $80.51 \pm 3.06$ & $69.35 \pm 3.24^{\mathrm{a}, \mathrm{b}}$ & $78.95 \pm 3.12^{\mathrm{a}, \mathrm{b}}$ \\
\hline
\end{tabular}

Results are presented as $\%$ of positive cells in total for the fasudil group only; no obvious positive staining was observed in the control or fasudil + XAV939 groups. ${ }^{\mathrm{a}} \mathrm{P}<0.05$ vs. $6 \mathrm{~h}$; and ${ }^{\mathrm{b}} \mathrm{P}<0.05$ vs. $24 \mathrm{~h}$. NSE, neuron-specific enolase; NF-M, neurofilament-M.

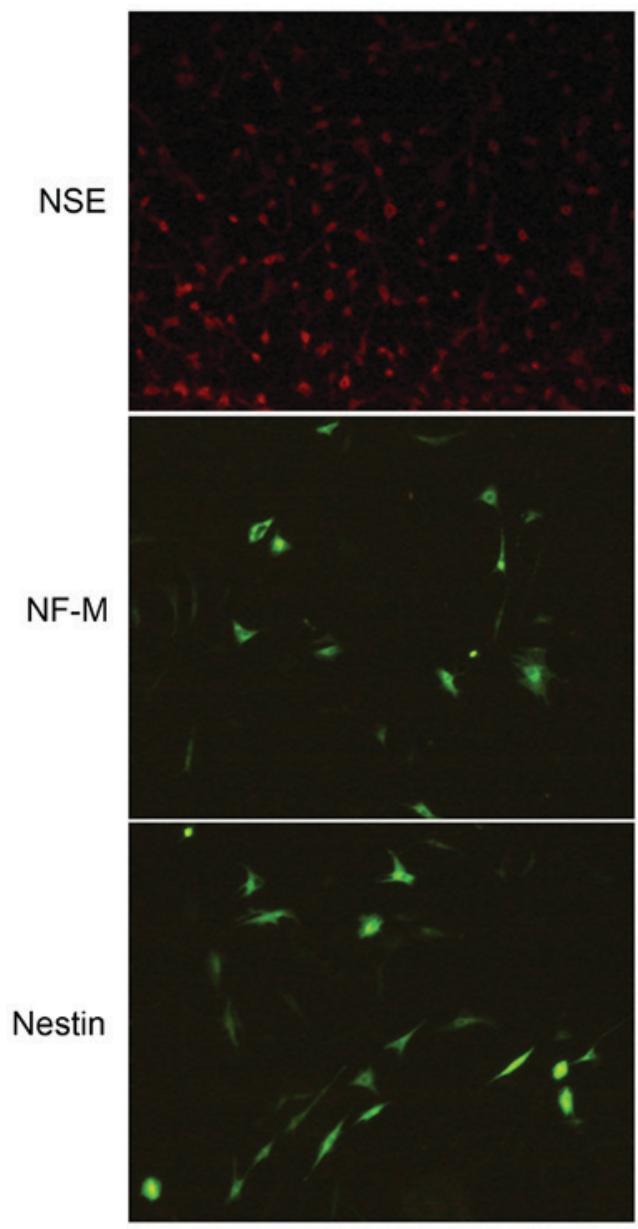

Figure 7. Immunofluorescent staining results of mesenchymal stem cells induced by fasudil for $48 \mathrm{~h}$. (magnification, x100). Staining results for NSE, NF-M and nestin. NSE, neuron-specific enolase; NF-M, neurofilament-M.

nestin (Table II), with a simple monopolar or bipolar appearance (data not shown), indicating that the induced cells were neural stem cells. After $24 \mathrm{~h}$ of induction, the average positive rate of immunofluorescent staining was $76.52 \%$ for NSE, $45.31 \%$ for NF-M ( $\mathrm{P}<0.05$ vs. $6 \mathrm{~h}$ induction; Table II) and $68.81 \%$ for nestin $(\mathrm{P}<0.05$ vs. $6 \mathrm{~h}$ induction; Table II), indicating that with time, MSCs gradually differentiated to neuron-like cells and expression of neuron-specific proteins, including NF-M and nestin, increased. After $48 \mathrm{~h}$ of fasudil induction, the average positive rate of immunofluorescent staining increased to $69.35 \%$ for NF-M ( $\mathrm{P}<0.05$ vs. 6 and $24 \mathrm{~h}$; Table II) and $78.95 \%$ for nestin $(\mathrm{P}<0.05$ vs. 6 and 24 h; Table II). There was no significant increase in the expression of NSE between 6 and $48 \mathrm{~h}$ of induction. (Table II). The immunofluorescence staining results of NSE, NF-M and nestin following induction with fasudil for $48 \mathrm{~h}$ are presented in Fig. 7.

\section{Discussion}

Studies have demonstrated that MSCs promote nerve repair following a brain hemorrhage or spinal cord injury (32-34). Kopen et al (35) injected mouse MSCs into the central nervous system of neonatal mice and observed morphological and phenotypic characteristics of neurons and astrocytes. Following this, a growing number of studies have demonstrated that MSCs, under certain conditions, appear to transform into neurons $(15,26,32)$. MSCs are easily obtained from autologous tissue and immune rejection does not occur following autologous transplantation. Furthermore, MSCs are easy to separate and culture in vitro, have a high gene transfection rate in vitro and are stable and effective at expressing exogenous genes. These advantages make MSCs more effective than neural stem cells in clinical application. Bone marrow MSCs have multiple differentiation capacity and, under specific conditions, are able to differentiate into osteoblasts, chondrocytes, adipocytes, hematopoietic cells, cardiomyocytes or neuronal cells (36). Given this, a number of studies have explored the mechanisms that are involved in the differentiation of MSCs into neural cells, including 3-isobutyl-1-methylxanthine and dibutyryl cyclic AMP (37), hepatocyte growth factor and vascular endothelial growth factor (38), retinoic acid and bFGF (39), glutathione (40) and the phosphatidylcholine-specific phospholipase C inhibitor D609 (41).

When MSCs differentiate into neurons, cells need to rebuild their cytoskeleton and the cell body shrinks to become spherical or conical and send out axons and dendrites, accompanied by the expression of neural cell-specific proteins. The RhoA/ROCK signaling pathway is primarily involved in cell migration, gene transcription, cell proliferation and apoptosis. Studies have demonstrated that ROCK inhibitors improve the survival rate of embryonic stem cells and decrease the apoptosis of neural precursor cells differentiated from embryonic stem cells (20). It has also been demonstrated that when using the ROCK inhibitor Y-27632, MSCs differentiate into neuron-like cells through cell-cycle arrest (42). Furthermore, cotreatment with the prolyl hydroxylase inhibitor FG-0041 and the ROCK inhibitor Y-27632 results in morphological changes of MSCs into neuron-like cells, increased neuronal marker expression and modifications of cell cycle-related gene expression consistent with the cell cycle arrest of MSCs (43). ROCK is a major effector molecule of intracellular myelin inhibitory signaling, and has an important role in the adjustment of axon growth. In addition to the inhibition of cellular proliferation, the Rho/ROCK pathway has a negative regulatory role in neuritogenesis, which is one of the first steps of neuronal differentiation (44-47). Activation of the Rho/ROCK pathway causes axonogenesis to be inhibited, whereas inhibition of this pathway induces the early outgrowth of neurites $(48,49)$. It has been previously reported that fasudil may inhibit the Rho/ROCK pathway to increase endothelial nitric oxide 
synthase (eNOS) expression, resulting in an increase in eNOS activity and NO production, and reduced oxygen free radical damage to the nerve cell membrane, which is important in the development and remodeling of nerves and the formation of neural networks $(50,51)$. Fasudil blocks the activity of ROCK by competing with ATP for the binding sites in the ROCK catalytic domain. Therefore, it not only inhibits the activities of intracellular free calcium, but also protein kinase and myosin light chain phosphatase, and thus the phosphorylation of the myosin light chain. This causes vascular smooth muscle to relax and blood vessels to expand to promote nervous growth and improve the recovery of neurological function following injury $(52,53)$. In the present study, the results demonstrated that fasudil induced MSCs to differentiate into neuron-like cells. Following induction by fasudil, the cell body of MSCs became smaller and round with slender processes, presenting a neuron-like cellular shape. Overtime, an increased number of neuron-like cells were observed, and some cells pulled into network-like structures. In addition, neuron-specific markers, including NSE, nestin, and NF-M were detected by RT-qPCR, western blot analysis and immunofluorescence staining, indicating that MSCs differentiated into neuron-like cells based on cell morphology and gene expression.

Various signaling pathways are involved in the differentiation of MSCs into neurons in vitro, including Notch, Sox and $\mathrm{Wnt} / \beta$-catenin pathways $(27,54)$. The $\mathrm{Wnt} / \beta$-catenin signaling pathway is a conserved signaling pathway and has key roles in the regulation of cell growth, migration and differentiation. $\beta$-catenin is a key molecule in the canonical Wnt signaling pathway. It interacts with a variety of cytokines to activate relevant downstream target genes, and the nuclear expression of $\beta$-catenin determines the activity of the canonical Wnt pathway. Previous studies have reported that $\beta$-catenin controls the growth of neural precursor cells and the balance of cell proliferation and differentiation (55). The present study investigated the role of the Wnt/ $\beta$-catenin pathway in fasudil-induced differentiation of MSCs into neuron-like cells. The results demonstrated that in the process of fasudil-induced differentiation of MSCs into neuron-like cells, fasudil increased $\beta$-catenin mRNA expression and the amount of $\beta$-catenin protein in the nucleus. By blocking the Wnt/ $\beta$-catenin pathway with the specific inhibitor XAV939, the $\beta$-catenin mRNA expression and the content of $\beta$-catenin in the nucleus was decreased, and the ability of fasudil to induce the differentiation of MSCs into neuron-like cells was reduced. In the fasudil + XAV939 group, no obvious changes in cell shape were observed after $6 \mathrm{~h}$, with limited cell body shrinkage and the appearance of some triangle-like cells, but with no cell processes. Furthermore, the expression of NSE, NF-M and nestin proteins was similar to the expression in the control group and there were no obvious positive immunofluorescent stained cells, indicating that the effect of fasudil on the differentiation of bone marrow MSCs into neuron-like cells was eliminated when the $\mathrm{Wnt} / \beta$-catenin pathway was inhibited.

Various factors in the microenvironment influence the differentiation of MSCs into different cell types, including chemokines, cytokines, growth factors, nutrients and hormones. The present study demonstrated that fasudil induced MSCs to differentiate into neuron-like cells, and the Wnt/ $\beta$-catenin pathway may have an important role in this process. Further studies examining the specific mechanisms involved in the process, such as how fasudil regulates the activity of the $\mathrm{Wnt} / \beta$-catenin pathway, are required. Further studies will also be required in order to investigate the functional characteristics of the induced cells, in order to test whether this method may be useful for clinical application in the future.

\section{Acknowledgements}

Not applicable.

\section{Funding}

No funding was received.

\section{Availability of data and materials}

The analyzed data sets generated during the present study are available from the corresponding author on reasonable request.

\section{Authors' contributions}

YH designed the present study and analyzed the data; XL and GH conceived the study and revised the manuscript; JW and WL performed the experiments.

\section{Ethics approval and consent to participate}

Ethical approval for animal experiments was obtained from the Committee on the Use of Live Animals in Teaching and Research of The Second Hospital of Tianjin Medical University (Tianjin, China).

\section{Patient consent for publication}

Not applicable.

\section{Competing interests}

The authors declare that they have no competing interests.

\section{References}

1. Alvarez-Dolado M, Pardal R, Garcia-Verdugo JM, Fike JR, Lee HO, Pfeffer K, Lois C, Morrison SJ and Alvarez-Buylla A: Fusion of bone-marrow-derived cells with Purkinje neurons, cardiomyocytes and hepatocytes. Nature 425: 968-973, 2003.

2. Bjornson CR, Rietze RL, Reynolds BA, Magli MC and Vescovi AL: Turning brain into blood: A hematopoietic fate adopted by adult neural stem cells in vivo. Science 283: 534-537, 1999.

3. Eglitis MA and Mezey E: Hematopoietic cells differentiate into both microglia and macroglia in the brains of adult mice. Proc Natl Acad Sci USA 94: 4080-4085, 1997.

4. Petersen BE, Bowen WC, Patrene KD, Mars WM, Sullivan AK, Murase N, Boggs SS, Greenberger JS and Goff JP: Bone marrow as a potential source of hepatic oval cells. Science 284: 1168-1170, 1999.

5. Wu J, Sun Z, Sun HS, Wu J, Weisel RD, Keating A, Li ZH, Feng ZP and Li RK: Intravenously administered bone marrow cells migrate to damaged brain tissue and improve neural function in ischemic rats. Cell Transplant 16: 993-1005, 2008.

6. Yamazaki Y, Kanno H, Maeda K, Yoshida T, Kobayashi N, Kubo A, Yamaguchi $Y$ and Saito T: Engrafted VHL peptide-delivered bone marrow stromal cells promote spinal cord repair in rats. Neuroreport 21: 287-292, 2010. 
7. Liu W, Jiang X, Fu X, Cui S, Du M, Cai Y and Xu R: Bone marrow stromal cells can be delivered to the site of traumatic brain injury via intrathecal transplantation in rabbits. Neurosci Lett 434: 160-164, 2008.

8. Chartoff EH, Damez-Werno D, Sonntag KC, Hassinger L, Kaufmann DE, Peterson J, McPhie D, Cataldo AM and Cohen BM: Detection of intranasally delivered bone marrow-derived mesenchymal stromal cells in the lesioned mouse brain: A cautionary report. Stem Cells Int 2011: 586586, 2011

9. Wakao S, Hayashi T, Kitada M, Kohama M, Matsue D, Teramoto N, Ose T, Itokazu Y, Koshino K, Watabe H, et al: Long-term observation of auto-cell transplantation in non-human primate reveals safety and efficiency of bone marrow stromal cell-derived Schwann cells in peripheral nerve regeneration. Exp Neurol 223: 537-547, 2010

10. Cuevas P, Carceller F, Dujovny M, Garcia-Gómez I, Cuevas B, González-Corrochano R, Diaz-González D and Reimers D: Peripheral nerve regeneration by bone marrow stromal cells. Neurol Res 24: 634-638, 2002.

11. Shimizu S, Kitada M, Ishikawa H, Itokazu Y, Wakao S and Dezawa M: Peripheral nerve regeneration by the in vitro differentiated-human bone marrow stromal cells with Schwann cel property. Biochem Biophys Res Commun 359: 915-920, 2007.

12. Choong PF, Mok PL, Cheong SK, Leong CF and Then KY: Generating neuron-like cells from BM-derived mesenchymal stromal cells in vitro. Cytotherapy 9: 170-183, 2007.

13. Kondo T, Johnson SA, Yoder MC, Romand R and Hashino E: Sonic hedgehog and retinoic acid synergistically promote sensory fate specification from bone marrow-derived pluripotent stem cells. Proc Natl Acad Sci USA 102: 4789-4794, 2005.

14. Song S and Sanchez-Ramos J: Preparation of neural progenitors from bone marrow and umbilical cord blood. Methods Mol Biol 438: 123-134, 2008.

15. Chen Y, Teng FY and Tang BL: Coaxing bone marrow stromal mesenchymal stem cells towards neuronal differentiation: Progress and uncertainties. Cell Mol Life Sci 63: 1649-1657, 2006.

16. Qin T, Fang F, Song M, Li R, Ma Z and Ma S: Umbelliferone reverses depression-like behavior in chronic unpredictable mild stress-induced rats by attenuating neuronal apoptosis via regulating ROCK/Akt pathway. Behav Brain Res 317: 147-156, 2017.

17. Li Q, Huang XJ, He W, Ding J, Jia JT, Fu G, Wang HX and Guo LJ: Neuroprotective potential of fasudil mesylate in brain ischemia-reperfusion injury of rats. Cell Mol Neurobiol 29: 169-180, 2009.

18. Alokam R, Singhal S, Srivathsav GS, Garigipati S, Puppala S, Sriram D and Perumal Y: Design of dual inhibitors of ROCK-I and NOX2 as potential leads for the treatment of neuroinflammation associated with various neurological diseases including autism spectrum disorder. Mol Biosyst 11: 607-617, 2015.

19. Li L, Zhi D, Shen Y, Liu K, Li H and Chen J: Effects of CC-chemokine receptor 5 on ROCK2 and P-MLC2 expression after focal cerebral ischaemia-reperfusion injury in rats. Brain Inj 30: 468-473, 2016.

20. Koyanagi M, Takahashi J, Arakawa Y, Doi D, Fukuda H, Hayashi H, Narumiya S and Hashimoto N: Inhibition of the Rho/ROCK pathway reduces apoptosis during transplantation of embryonic stem cell-derived neural precursors. J Neurosci Res 86: 270-280, 2008.

21. Satoh S, Toshima Y, Hitomi A, Ikegaki I, Seto M and Asano T: Wide therapeutic time window for Rho-kinase inhibition therapy in ischemic brain damage in a rat cerebral thrombosis model. Brain Res 1193: 102-108, 2008.

22. Ding J, Li QY, Yu JZ, Wang X, Sun CH, Lu CZ and Xiao BG: Fasudil, a Rho kinase inhibitor, drives mobilization of adult neural stem cells after hypoxia/reoxygenation injury in mice. Mol Cell Neurosci 43: 201-208, 2010.

23. Lee HS, Kim KS, Lim HS, Choi M, Kim HK, Ahn HY, Shin JC and Joe YA: Priming Wharton's jelly-derived mesenchymal stromal/stem cells with ROCK inhibitor improves recovery in an intracerebral hemorrhage model. J Cell Biochem 116: 310-319, 2015.

24. Zhao EY, Wang LD, Wen QQ, Guan WJ, Jing LJ, Peng T, Wen GQ and Jia YJ: Effect of notch signaling on differentiation of rat marrow mesenchymal stem cells into neurons induced by fasudil hydrochloride. Zhongguo Ying Yong Sheng Li Xue Za Zhi 26: 428-432, 2010 (In Chinese)

25. Zhao EY, Jia YJ, Wang DM, Wen GQ, Guan WJ, Jing LJ and Deng YD: Effect of p65 gene inhibited by siRNA on differention of rat marrow mesenchymal stem cells into neurons. Zhongguo Ying Yong Sheng Li Xue Za Zhi 31: 254-258, 2015 (In Chinese).
26. Wu R, Tang Y, Zang W, Wang Y, Li M, Du Y, Zhao G and Xu Y: MicroRNA-128 regulates the differentiation of rat bone mesenchymal stem cells into neuron-like cells by Wnt signaling. Mol Cell Biochem 387: 151-158, 2014

27. Yu Q, Liu L, Duan Y, Wang Y, Xuan X, Zhou L and Liu W: Wnt/ $\beta$-catenin signaling regulates neuronal differentiation of mesenchymal stem cells. Biochem Biophys Res Commun 439: 297-302, 2013

28. Li L, Tam L, Liu L, Jin T and Ng DS: Wnt-signaling mediates the anti-adipogenic action of lysophosphatidic acid through cross talking with the Rho/Rho associated kinase ROCK) pathway. Biochem Cell Biol 89: 515-521, 2011.

29. Zhao Y, Zhang Q, Xi J, Xiao B, Li Y and Ma C: Neuroprotective effect of fasudil on inflammation through PI3K/Akt and Wnt/ $\beta$-catenin dependent pathways in a mice model of Parkinson's disease. Int J Clin Exp Pathol 8: 2354-2364, 2015

30. Zhao YF, Zhang Q, Xi JY, Li YH, Ma CG and Xiao BG: Multitarget intervention of Fasudil in the neuroprotection of dopaminergic neurons in MPTP-mouse model of Parkinson's disease. J Neurol Sci 353: 28-37, 2015.

31. Livak KJ and Schmittgen TD: Analysis of relative gene expression data using real-time quantitative PCR and the 2(-Delta Delta C(T)) method. Methods 25: 402-408, 2001.

32. Long X, Olszewski M, Huang W and Kletzel M: Neural cell differentiation in vitro from adult human bone marrow mesenchymal stem cells. Stem Cells Dev 14: 65-69, 2005.

33. Ge L, Liu K, Liu Z and Lu M: Co-transplantation of autologous OM-MSCs and OM-OECs: A novel approach for spinal cord injury. Rev Neurosci 27: 259-270, 2016.

34. Kumagai G, Tsoulfas P, Toh S, McNiece I, Bramlett HM and Dietrich WD: Genetically modified mesenchymal stem cells (MSCs) promote axonal regeneration and prevent hypersensitivity after spinal cord injury. Exp Neurol 248: 369-380, 2013.

35. Kopen GC, Prockop DJ and Phinney DG: Marrow stromal cells migrate throughout forebrain and cerebellum, and they differentiate into astrocytes after injection into neonatal mouse brains. Proc Natl Acad Sci USA 96: 10711-10716, 1999.

36. Bianco P, Robey PG and Simmons PJ: Mesenchymal stem cells: Revisiting history, concepts, and assays. Cell Stem Cell 2: 313-319, 2008.

37. Deng W, Obrocka M, Fischer I and Prockop DJ: In vitro differentiation of human marrow stromal cells into early progenitors of neural cells by conditions that increase intracellular cyclic AMP. Biochem Biophys Res Commun 282: 148-152, 2001.

38. Bae KS, Park JB, Kim HS, Kim DS, Park DJ and Kang SJ: Neuron-like differentiation of bone marrow-derived mesenchymal stem cells. Yonsei Med J 52: 401-412, 2011.

39. Kim BJ, Seo JH, Bubien JK and Oh YS: Differentiation of adult bone marrow stem cells into neuroprogenitor cells in vitro. Neuroreport 13: 1185-1188, 2002

40. Sagara J and Makino N: Glutathione induces neuronal differentiation in rat bone marrow stromal cells. Neurochem Res 33: 16-21, 2008.

41. Wang N, Xie K, Huo S, Zhao J, Zhang S and Miao J: Suppressing phosphatidylcholine-specific phospholipase $\mathrm{C}$ and elevating ROS level, NADPH oxidase activity and Rb level induced neuronal differentiation in mesenchymal stem cells. J Cell Biochem 100: 1548-1557, 2007.

42. Pacary E, Legros H, Valable S, Duchatelle P, Lecocq M, Petit E, Nicole $\mathrm{O}$ and Bernaudin M: Synergistic effects of $\mathrm{CoCl}(2)$ and ROCK inhibition on mesenchymal stem cell differentiation into neuron-like cells. J Cell Sci 119: 2667-2678, 2006.

43. Pacary E, Petit E and Bernaudin M: Concomitant inhibition of prolyl hydroxylases and ROCK initiates differentiation of mesenchymal stem cells and PC12 towards the neuronal lineage. Biochem Biophys Res Commun 377: 400-406, 2008.

44. Dickson BJ: Rho GTPases in growth cone guidance. Curr Opin Neurobiol 11: 103-110, 2001.

45. Sit ST and Manser E: Rho GTPases and their role in organizing the actin cytoskeleton. J Cell Sci 124: 679-683, 2011

46. Begum R, Nur-E-Kamal MS and Zaman MA: The role of Rho GTPases in the regulation of the rearrangement of actin cytoskeleton and cell movement. Exp Mol Med 36: 358-366, 2004.

47. Luo L: Rho GTPases in neuronal morphogenesis. Nat Rev Neurosci 1: 173-180, 2000.

48. Bito H, Furuyashiki T, Ishihara H, Shibasaki Y, Ohashi K, Mizuno K, Maekawa M, Ishizaki T and Narumiya S: A critical role for a Rho-associated kinase, p160ROCK, in determining axon outgrowth in mammalian CNS neurons. Neuron 26: 431-441, 2000 
49. Hirose M, Ishizaki T, Watanabe N, Uehata M, Kranenburg O, Moolenaar WH, Matsumura F, Maekawa M, Bito H and Narumiya S: Molecular dissection of the Rho-associated protein kinase (p160ROCK)-regulated neurite remodeling in neuroblastoma N1E-115 cells. J Cell Biol 141: 1625-1636, 1998.

50. Choi BH, Zhu SJ, Kim BY, Huh JY, Lee SH and Jung JH: Transplantation of cultured bone marrow stromal cells to improve peripheral nerve regeneration. Int J Oral Maxillofac Surg 34 537-542, 2005.

51. Shin HK, Salomone S, Potts EM, Lee SW, Millican E, Noma K, Huang PL, Boas DA, Liao JK, Moskowitz MA and Ayata C: Rho-kinase inhibition acutely augments blood flow in focal cerebral ischemia via endothelial mechanisms. J Cereb Blood Flow Metab 27: 998-1009, 2007.

52. Impellizzeri D, Mazzon E, Paterniti I, Esposito E and Cuzzocrea S: Effect of fasudil, a selective inhibitor of Rho kinase activity, in the secondary injury associated with the experimental model of spinal cord trauma. J Pharmacol Exp Ther 343: 21-33, 2012.
53. Fournier AE, Takizawa BT and Strittmatter SM: Rho kinase inhibition enhances axonal regeneration in the injured CNS. J Neurosci 23: 1416-1423, 2003.

54. Wang S, Kan Q, Sun Y, Han R, Zhang G, Peng T and Jia Y: Caveolin-1 regulates neural differentiation of rat bone mesenchymal stem cells into neurons by modulating Notch signaling. Int J Dev Neurosci 31: 30-35, 2013.

55. Zechner D, Fujita Y, Hülsken J, Müller T, Walther I, Taketo MM, Crenshaw EB III, Birchmeier W and Birchmeier C: beta-Catenin signals regulate cell growth and the balance between progenitor cell expansion and differentiation in the nervous system. Dev Biol 258: 406-418, 2003.

(i) (9) This work is licensed under a Creative Commons Attribution-NonCommercial-NoDerivatives 4.0 International (CC BY-NC-ND 4.0) License. 